\title{
Genetics of club foot in Maori and Pacific people
}

\author{
Cyril Chapman, N Susan Stott, Ramari Viola Port, Richard O Nicol
}

\begin{abstract}
The role of major gene and multifactorial inheritance in the aetiology of club foot in the New Zealand Polynesian population was studied using 287 New Zealand Maori and Pacific club foot families. The club foot family data were analysed by complex segregation analysis under the mixed model using the computer program POINTER. This analysis shows that the best genetic model for club foot in this population is a single dominant gene with a penetrance of $33 \%$ and a predicted gene frequency of $0.9 \%$. These data provide a scientific foundation for molecular studies in the Maori and Polynesian population to identify putative club foot genes.

(7 Med Genet 2000;37:680-683)
\end{abstract}

Keywords: club foot; New Zealand Maori; complex segregation analysis

Idiopathic talipes equinovarus or club foot is a deformity of the foot and lower leg present at birth that is characterised by rigid (nonreducible) equinus of the ankle, varus of the hindfoot, and adductus of the forefoot. Males are more commonly affected than females by a ratio of 2 to 1 and the incidence of bilaterality is $50 \% .^{1}$ Most club feet occur as isolated congenital deformities but a small percentage are associated with either a neuromuscular disorder or a generalised syndrome, for example, spina bifida, arthrogryposis, or diastrophic dwarfism. ${ }^{12}$

Club foot was well known in the early New Zealand Maori population. The Maori word for club foot is "waehape", "wae" meaning foot and "hape" meaning broken or crooked. Oral history handed down tribally records that male children who had a club foot were often given the name Hape. ${ }^{3}$ It is possible that some children who had club feet were left to die as was the practice in some Polynesian groups. ${ }^{4}$ However, oral history also records the club foot being broken immediately after birth to improve the position of the foot. ${ }^{3}$ These practices have now disappeared and children are treated by strapping or serial casting followed by surgical correction. ${ }^{5}$

The high incidence of club foot in the New Zealand Maori has been confirmed in two previous studies which found the prevalence to be between 6 to 7 per $1000 .{ }^{35}$ Similar birth prevalences have also been reported in the Hawaiian and the Tongan populations ${ }^{7}$ (N I B Stratton, personal communication, 1999). In contrast, the birth prevalence of club foot in the Chinese population is only 0.57 per $1000,{ }^{7}$ while the prevalence in the white population is reported to be 1 to 3 per $1000 .^{248}$
The aetiology of club foot is unknown but various theories have been suggested, including intrauterine mechanical factors or subtle neuromuscular causes. ${ }^{1}$ A regional growth disturbance on the medial side of the foot has also been proposed. ${ }^{9}$ Several genetic studies have suggested that the prevalence of club feet in the white population is best explained by a single gene with a polygenic component. ${ }^{210}$ Asians, conversely, best fit a model of multifactorial inheritance without major gene effects. ${ }^{11}$

In this study we undertook an analysis of 287 Maori and Pacific Island families who had club foot to determine whether, in this population, genetic inheritance is an important factor in the aetiology of club foot.

\section{Materials and methods}

The Ethical Review Committee approved the study. Six New Zealand centres with a high density of New Zealand Polynesian and Maori population as defined by the 1991 New Zealand Census were identified (Auckland, Tauranga, Gisborne, Rotorua, Napier, and Whangarei). Families of the probands were approached and enrolled in the study by participating orthopaedic surgeons in each centre. Families were then interviewed at each centre with family pedigrees being constructed by one of three authors (R V Port, C Chapman, or R Nicol). R V Port is bilingual in Maori and English, which greatly facilitated accurate information retrieval.

All probands had idiopathic talipes equinovarus manifested by equinus of the ankle, varus of the hindfoot, and adductus of the forefoot. The diagnosis of idiopathic talipes equinovarus was confirmed by review of the medical records and clinical examination by the local orthopaedic surgeon. No other abnormalities were present and children with club foot secondary to neuromuscular disease or congenital syndromes were excluded. Probands with postural talipes equinovarus or simple metatarsus adductus were also excluded.

A total of 287 families were included in the study. Of these 287 families, 237 families were interviewed in this study. Fifty family pedigrees had been previously collected by $\mathrm{Dr}$ Rodney Beals ${ }^{4}$ in Auckland in 1973 and these were included in the analysis giving the total of 287 families. These 50 pedigrees were collected to the same standard as the other family data. A representative pedigree is shown in fig 1 .

For each family, the age, sex, date of birth, and relationship to the proband were collected. Full pedigrees were collected out to the cousins of the probands and then extended beyond that for affected subjects only. The affected status of all first, second, and third
2 February 2000

Accepted for publication

3 May 2000 


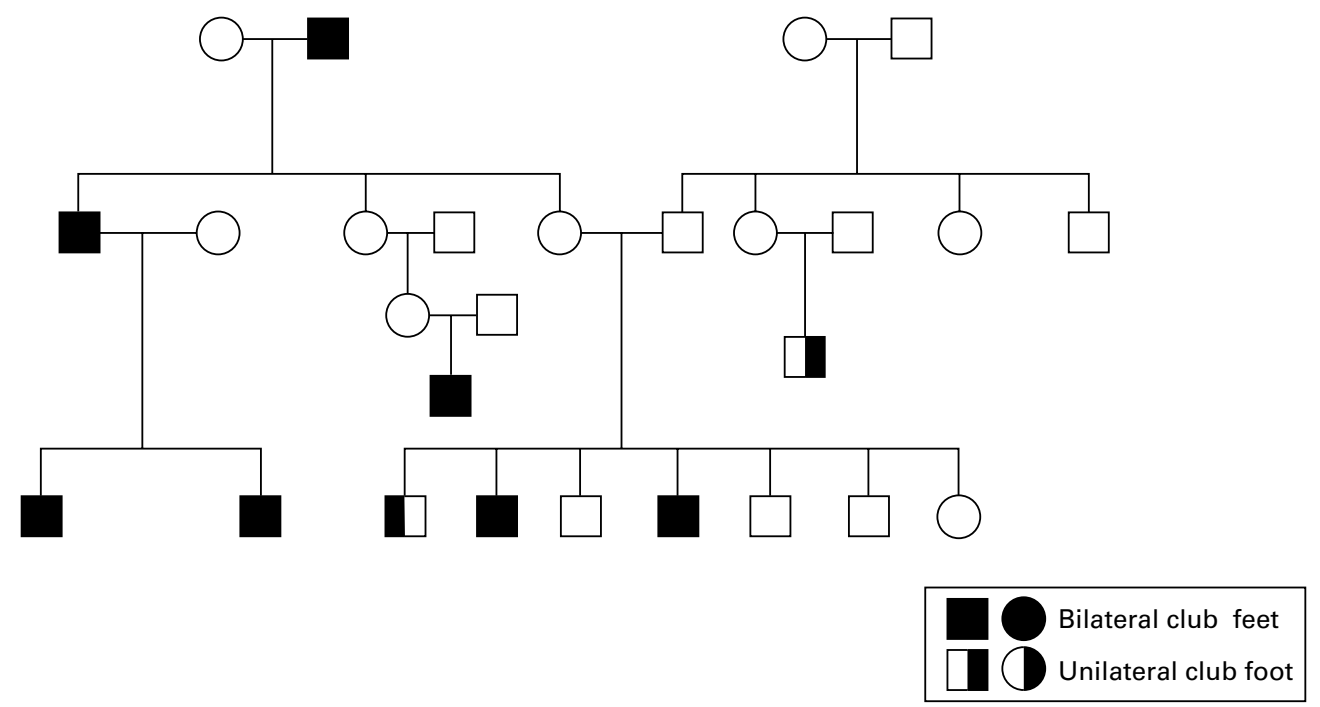

Figure 1 Representative family pedigree.

degree relatives of the proband was determined by interview and medical records. A positive history of club foot was based upon the presence of the typical deformity of the foot at birth and the treatment regimen.

STATISTICAL ANALYSIS

From the family information, nuclear family information was extracted and submitted to complex segregation analysis using the POINTER computer program. ${ }^{12}$ For the analysis, POINTER deals with separate sibships containing at least one affected person from the full pedigree and does not use the pedigree as a whole. Nuclear families without any affected member, therefore, do not get included in the analysis. The genetic model embodied in this program includes a multifactorial component (often termed a polygenic component) together with a single major gene. The word "major" is used to distinguish this genetic factor from the host of minor genetic factors that are assumed to contribute to the multifactorial component.

There are four genetic parameters estimated under the mixed model; the heritability $(\mathrm{H})$, the gene frequency of the abnormal allele (q), the degree of dominance $(\mathrm{d}, 0.0$ implies recessive, 1.0 full dominance), and the separation of the two homozygous means ( $t$ ). It is assumed that there is an underlying scale of liability to club foot that is unmeasurable, but which has a threshold beyond which a person is affected. A combination of environmental factors and genetic factors contribute to the intrinsic liability to develop club foot, with the environmental factors unmeasured and random. The model can include a parameter for effects that apply in childhood but this was not estimated in this analysis as it was felt that this was not of direct relevance to a condition presenting at birth.

Under POINTER, it is necessary to specify an ascertainment model. Because of the complexity of our data ascertainment, this cannot be specified precisely. Analysis of ascertainment is a complex problem not fully resolved. ${ }^{13}$
Accordingly, we assumed incomplete selection and estimated the ascertainment probability $\pi$ by examining the distribution of ascertained subjects among the affected subjects within sibships. ${ }^{14}$ However, because of concerns about the sampling model, the analyses were also carried out using truncate selection with the ascertainment probability $\pi$ set to 1.0 , with multiple incomplete ascertainment using an ascertainment probability of 0.95 , and with the estimated value.

The analysis proceeds by estimating the likelihood of the set of families under a variety of models using chi-square tests. In large sample theory, a general hypothesis can be compared with a sub-hypothesis by taking twice the difference between the logarithms of the likelihoods of the two hypotheses and assuming that they are distributed as a chi-square with degrees of freedom equal to the difference in the number of parameters estimated in the two models. Where a parameter estimate meets a boundary condition (such as the heritability being no greater than 1.0), the precise number of degrees of freedom is debated. A conservative estimate assuming the larger figure was used. As our data came from two separate collections, the parameter estimates were checked for homogeneity by comparing the sum of the logarithms of the likelihoods for the separate data sets with the likelihood when they were analysed together. Twice the difference is distributed as a chi-square with one degree of freedom.

\section{Results}

PATIENT POPULATION

The 50 Maori family trees constructed by Dr R Beals have been previously reported, ${ }^{4}$ but are summarised in table 1 . The other 237 Polynesian sib family trees in this study were constructed with the proband originating from one of six centres around New Zealand. Of these 237 probands, $63 \%$ were male and $37 \%$ were female. The racial origin of the proband was predominantly Maori (189), but a small number of Pacific Island families were included from Samoa (15), Tonga (13), Cook Islands 
Table 1 Demographics of study population

\begin{tabular}{llll}
\hline & $\begin{array}{l}\text { Beals data } \\
\text { (50 patients) }\end{array}$ & $\begin{array}{l}\text { Current data } \\
\text { (237 patients) }\end{array}$ & $\begin{array}{l}\text { Total (287 } \\
\text { patients) }\end{array}$ \\
\hline $\begin{array}{l}\text { Gender } \\
\text { Male }\end{array}$ & 31 & 150 & 181 \\
Female & 19 & 87 & 106 \\
Site of involvement & & \\
Right & 16 & 60 & 76 \\
Left & 8 & 40 & 48 \\
Bilateral & 26 & 137 & 163 \\
No of affected subjects per family pedigree & \\
1 & 10 & 89 & 99 \\
2 & 7 & 65 & 72 \\
3 & 12 & 44 & 56 \\
4 & 5 & 13 & 18 \\
$>4$ & 16 & 26 & 42 \\
\hline
\end{tabular}

Table 2 Results of segregation analysis for all families

\begin{tabular}{|c|c|c|c|c|}
\hline Model & $\begin{array}{l}\text { Multifactorial } \\
q=t=d=0.0\end{array}$ & $\begin{array}{l}\text { Recessive } \\
\text { major gene } \\
H=d=0.0\end{array}$ & $\begin{array}{l}\text { Dominant } \\
\text { major gene } \\
H=0.0 ; \\
d=1.0\end{array}$ & $\begin{array}{l}\text { General } \\
\text { model }\end{array}$ \\
\hline$q$ & - & 0.0077 & 0.0088 & 0.0088 \\
\hline $\mathrm{t}$ & - & 2.51 & 2.51 & 2.51 \\
\hline d & - & 0.0 & 1.0 & $->1.0$ \\
\hline $\mathrm{H}$ & 0.9485 & - & - & $\rightarrow 0.0$ \\
\hline$-2 \mathrm{LnL}$ & 944.89 & 942.15 & 932.70 & 932.70 \\
\hline
\end{tabular}

(13), Niue (6), and Tuvalu (1). In many families, members were from several different Pacific Island groups or had a mixed ethnicity of New Zealand Maori plus Pacific Island. We used the definition developed by the New Zealand Census Department to define the primary racial group of each family.

The 237 Polynesian family pedigrees consisted of 6846 subjects. The pedigrees ranged in size from five to 105 with average size of 29 and $84 \%$ of them included three generations or more. The average number of affected subjects per family tree was 2.4 . Of the families with more than one affected member, $22(14 \%)$ had one affected parent and $26(17 \%)$ had one or more affected sibs.

\section{GENETIC ANALYSIS}

From the distribution of ascertainments within sibships the ascertainment probability $\pi$ was estimated to be 0.31 . The analyses cited below use this value. Analyses using the alternative values for $\pi$ discussed above were little different, with chi-square values very similar to those quoted. The results of the segregation analysis are presented in table 2 .

A single dominant gene clearly provides the best fitting model among those shown. The chi-square value comparing the general model with the multifactorial model is 12.19 with 3 degrees of freedom $(p<0.001)$. A recessive model is similarly rejected $\left(\chi^{2}=9.45,2 \mathrm{df}\right.$, $\mathrm{p}<0.0 .01)$. Estimating the likelihood of the general model for each of the two data sets (Beals's dataset and our patient data) under the dominant major gene model gives a combined $-2 \mathrm{LnL}$ of 929.77 , so that the chi-square value for homogeneity between the two data sets is $932.70-929.77$, or 2.93 with 1 df $(\mathrm{p}=0.1)$.

Under the dominant major gene model, the frequency of the abnormal allele is about $0.9 \%$, with a penetrance of $33 \%$ in heterozygotes and homozygotes. This implies that about $83 \%$ of affected subjects in this population will be heterozygous.

\section{Discussion}

There have been three previous studies of possible genetic factors in the aetiology of club foot among Polynesians in New Zealand. The first was undertaken in Rotorua by Veale et $a l^{6}$ in 1966, who considered the birth incidence in Maori to be 6 per 1000 and found support for a multifactorial model with a heritability of $70 \%$. At that time, complex segregation analysis under a mixed genetic model was not possible. Beals ${ }^{4}$ reported on 50 families ascertained from Middlemore Hospital but was unable to test specifically for single gene effects. Cartlidge $^{815}$ reported on the epidemiology (including family history) of club foot in the Polynesian child, but did not perform any genetic analyses. Our study supports the findings of these previous reports and shows that in the Maori and Pacific population, there is a very significant probability that club foot is caused by a single dominant gene.

The only other paper to report on a complex segregation analysis of club foot in Polynesians has been that of Yang et al. ${ }^{11}$ They found support for a mixed model, with an almost fully dominant major gene with a gene frequency of $4.7 \%$ combined with a polygenic component with a heritability of $27 \%$. This compares with our best fitting model which suggests a fully dominant major gene with a gene frequency of $0.9 \%$ and no polygenic component. Both studies provide clear support for a major gene contributing substantially to the cause of club foot in Polynesians. However, our model suggests a lower gene frequency but with a much higher penetrance. The reasons for these differences are not obvious but may relate to differences in the genetic histories of New Zealand Maori and Hawaiian Polynesians.

Complex segregation analysis has also been used in the white population to assess the possibility of genetic inheritance. A study of 143 white pedigrees in Iowa suggested a single dominant gene in combination with residual factors shared by sibs. ${ }^{2}$ Wang et $a l^{10}$ also found a largely dominant major gene $(\mathrm{d}=0.82)$ with an additional multifactorial component. Very similar findings were noted by Yang et $a l,{ }^{11}$ although their study was limited by the small number of white families. A fourth study, performed on 173 club foot families in Texas (including 93 white and 48 Hispanic families), found that the recessive mixed model was the best fitting model with no differences because of ethnicity. ${ }^{16}$ In all these studies, the number of families with more than two involved family members was small. For example, in the study by Rebbeck et al only 20 families had two or more members involved. This compares with our study in which 116 families of the 287 total have three or more members with club foot.

In summary, this study confirms the genetic background of club foot in Polynesians by using both linkage analysis and association studies. We have found that the likelihood of affected subjects carrying a copy of the gene 
predisposing to club foot is sufficiently high in this population that any family with multiple affected members is almost certain to be carrying a copy of this gene. These families would be good candidates for genomic screening to identify the putative "club foot gene".

This study was conducted at the Starship Children's Hospital and Northern Regional Genetics Services, Auckland Hospital, Auckland, New Zealand. We would like to thank the following orthopaedic surgeons who assisted in the recruitment of patients to the study: Mr Denis Atkinson, Napier Hospital; Mr Ross Bohm, Rotorua Hospital; Mr Chris Dawe, Tauranga Hospital; Professor Harley Gray, Middlemore Hospital; Mr Ian Kelman, Cook Hospital, Gisborne; Mr Ian Peters, Whangarei Hospital, and Mr Garnet Tregonning, Middlemore Hospital. the family data previously collected by Dr Rodney Beals. Expert secretarial assistance was provided by Ms Christine Expert secretarial assistance was provided by Ms Christine 250) Research Foundation (grant no 250) to Cyril Chapman and
Richard Nicol.

1 Sullivan JA. The child's foot. In: Lovell and Winter's pediatric orthopedics. 4th ed. Philadelphia: Lippincott-Raven, 1996.

2 Rebbeck TR, Dietz FR, Murray JC, Buetow KH. A singlegene explanation for the probability of having idiopathic gene explanation for the probability of having idiopath.

3 talipes equinovarus. Am f Hum Genet 1993;53:1051-63. to disability: clubfoot. Thesis, University of Auckland, 1995.
4 Beals RK. Club foot in Maori: a genetic study of 50 kindreds. NZ Med f 1978;88:144-6.

5 Brougham DI, Nicol RO. Use of the Cincinnati incision in congenital talipes equinovarus. $\mathcal{F}$ Pediatr Orthop 1988;8: 696-8.

6 Veale AMO, Tapsell PW, Tyler KR. Clubfoot in Maoris. In: Crow JF, Neel JV, eds. Proceedings of the Third International Congress of Human Genetics, 5-10 September 1966. Baltimore: Johns Hopkins University Press, 1967:102.

7 Chung CS, Nemechek RW, Larsen IJ, Ching GH. Genetic and epidemiological studies of clubfoot in Hawaii. General and medical considerations. Hum Hered 1969;19:321-42.

8 Cartlidge I. Observations on the epidemiology of club foot in Polynesian and Caucasian populations. $\mathcal{F}$ Med Genet 1984;21:290-2.

9 Dietz FR. On the pathogenesis of clubfoot. Lancet 1985;16: 388-90.

10 Wang JH, Palmer RM, Chung CS. The role of major gene in clubfoot. Am f Hum Genet 1988;42:772-6.

1 Yang HY, Chung CS, Nemechek RW. A genetic analysis of clubfoot in Hawaii. Genet Epidemiol 1987;4:299-306.

2 Lalouel JM, Morton NE. Complex segregation analysis with pointers. Hum Hered 1981;31:312-21.

13 Shute NC, Ewens WJ. A resolution of the ascertainment sampling problem. III. Pedigrees. Am $f$ Hum Genet 1988;43:387-95.

14 Morton NE. Estimation of demographic parameters from isolation by distance. Hum Hered 1982;32:37-41.

15 Cartlidge IJ. Clubfoot in the Polynesian: an epidemiology survey. NZ Med f 1983;96:515-17.

16 De Andrade M, Barnholtz JS, Amos CI, Lochmiller C, Scott A, Risman M, and Hecht JT. Segregation analysis of idiopathic talipes equinovarus in a Texan population. Am $\mathcal{F}$ idiopathic talipes equinovar
Med Genet 1998;79:97-102 